\title{
APLIKASI ENSEMBLE EMPIRICAL MODE DECOMPOSITION (EEMD) PADA SINYAL MIKROSEISMIK UNTUK IDENTIFIKASI DINAMIKA HIDROTERMAL BAWAH PERMUKAAN, STUDI KASUS DAERAH POTENSI GEOTERMAL GUNUNG LAMONGAN JAWA TIMUR
}

\author{
Tri Martha Kusuma Putra ${ }^{1)}$, Widya Utama ${ }^{2)}$, Makky S. Jaya ${ }^{3)}$ \\ ${ }^{1)}$ Hitay Energy Indonesia, ${ }^{2)}$ Jurusan Teknik Geofisika, ITS, ${ }^{3)}$ GFZ Helmholtz Center, ICGR, Potsdam - Germany \\ e-mail: tmkp.putra@gmail.com
}

\begin{abstract}
Abstrak. Proses reduksi noise sinyal non-linear dan non-stasioner dilakukan dengan mendekomposisi data atau sinyal utama menjadi sejumlah sinyal yang disebut IMF (Intrinsik Mode Function). Metode reduksi noise yang digunakan adalah Empirical Mode Decomposition (EMD). EMD menguraikan sinyal seismik menjadi beberapa osilasi komponen intrinsik. Setiap komponen dari Fungsi Mode intrinsik (IMF) memiliki frekuensi yang bervariasi sesuai dengan karakteristik wilayah. Metode Ensemble Empirical Mode Decomposition (EEMD) sebagai pengembangan dari metode Empirical Mode Decomposition (EMD) yang dikembangkan oleh Zhaohua Wu dan Norden E. Huang (2009). Proses reduksi noise menggunakan metode EEMD digunakan untuk mendapatkan even lokal. Even lokal diasumsikan sebagai even yang berasal dari dinamika hidrotermal bawah permukaan. Studi kasus penelitian ini adalah wilayah potensi geotermal Gunung Lamongan, Provinsi Jawa Timur. Akusisi dilakukan selama 24 jam pada tanggal 10 Mei 2011 menggunakan 5 stasiun mikroseismik. Alat mikroseismik merupakan alat DSS Cube EDL yang dikembangkan oleh GFZ memiliki pita frekuensi 4,5 - $120 \mathrm{~Hz}$. Tercatat terdapat 8 even lokal dan 1 even regional yang berasal dari gempa tektonik. Gempa tektonik yang tercatat merupakan gempa yang terjadi di utara Molucca. Penentuan even lokal didasarkan pada 2 kriteria utama yaitu rentang jeda waktu gelombang $\mathrm{P}$ antar stasiun (0,3 - 0,5 detik) dan memiliki frekuensi rendah antara 1 hingga $6 \mathrm{~Hz}$. Jeda waktu antar stasiun terjadi karena adanya perbedaan jarak antar stasiun dan kondisi bawah permukaan. Hasil analisa dapat dilakukan delineasi daerah seismik aktif yang berada di bagian utara Gunung Lamongan. Tampak adanya pola kerucut dan kemunculan manifestasi yang memperkuat bahwa adanya dinamika hidrotermal yang sebagian besar di bagian utara Gunung Lamongan. Hasil penelitian ini merupakan studi pendahuluan untuk melakukan metode pengukuran mikroseismik dengan pita frekuensi yang lebih lebar $(0,001-2000 \mathrm{~Hz})$ dan sebagai refrensi untuk akusisi metode geofisika lebih lanjut.
\end{abstract}

Kata Kunci: mikroseismik, EEMD, IMF, Gunung Lamongan.

Abstract. Noise reduction of non-linear and non-stationary signal has been performed by decomposing the main signal to some Intrinsic Mode Function (IMF) signals. The noise reduction method is Empirical Mode Decomposition (EMD) which splits the seismic wave into some intrinsic oscillation components. Each IMF component has its own frequency according to the region properties. Ensemble Empirical Mode Decomposition (EEMD) method as the developed method of EMD is developed by Zhaohua Wu and Norden E. Huang in 2009. Noise reduction is using EEMD method to obtain the local event which is assumed as an event from subsurface hydrothermal dynamics. The case study of this research is geothermal potential area of Lamongan Mountain, East Java. Acquisition have been performed for 24 hours on May, 10 2011 using five microseismc stations. The microseismc tool is DSS Cube EDL which is developed by GFZ and has a frequency band between $4,5-120 \mathrm{~Hz}$. The result shows that there are eight local events and one regional event from tectonic earthquake in Northern Molucca. Local event determination is based on two main criteria, they are range of $P$ wave delay time between two stations $(0,3-0,5$ seconds) and low frequency $(1-6 \mathrm{~Hz})$. Delay time between two stations can occur because of the length difference between one station to another and because of the subsurface condition. Analysis result shows that the delineation of seismic area in Northern Lamongan Mountain is possibly occurred. Furthermore, there are cone patterns and manifestation in the Northern Lamongan Mountain as the signs that hydrothermal dynamics occur in that area. This result can be a preliminary study to do more microseismc measurement with a wider frequency band $(0,001-2000 \mathrm{~Hz})$ and also can be a reference for the next geophysical method acquisition.

Keywords: microseismic, EEMD, IMF, Lamongan Mountain. 


\section{PENDAHULUAN}

Mikroseismik atau mikrotremor merupakan salah satu metode seismik pasif yang merekam getaran bersumber dari alam, seperti aktivitas gunung api, ombak, meteorologi, perkotaan (aktifitas manusia), pergerakan fluida, dan lain sebagainya. Metode mikroseismik ini biasanya digunakan pada kegiatan eksplorasi atau pengembangan wilayah eksploitasi hidrokarbon, pertambangan, geotermal, dan geoteknik. Pada studi kasus penelitian ini, metode mikroseismik digunakan untuk kegiatan eksplorasi geotermal. Keberadaan reservoir geotermal dapat diidentifikasi berdasarkan frekuensi yang timbul akibat pergerakan fluida (hidrotermal) di ruang pori batuan.

Dalam identifikasi dinamika hidrotermal dilakukan pemisahan sinyal dengan noise anthropogenic dan membandingkan kesamaan karakteristik even (frekuensi \& watu terbentuknya even) pada masing-masing stasiun (multiplet). Noise anthropogenic merupakan sinyal mikrotremor yang bersumber dari getaran gunung api, perkotaan (aktifitas manusia), ombak, meteorologi, dan badai (Claudet, Cotton, \& Yves Bard 2006, hh. 205-227). Salah satu metode untuk mereduksi anthropogenic noise ialah Ensemble Empirical Mode Decomposition (EEMD). Metode ini merupakan pengembangan dari Empirical Mode Decomposition (EMD) yang dikembangkan oleh Zhaohua Wu dan Norden E. Huang (2009), serta Jiang Zhang (2010) untuk menghilangkan mode mixing (Saenger et al. 2009 vol. 74, hh. 29-40); (Chen et al. 2012, hh. 1-5).

Sinyal mikroseismik yang telah terfilter akan dilakukan pemilihan even dengan metode multiplet. Pemilihan even didasarkan pada kejadian even pada waktu yang sama dan memiliki frekuensi rendah yang berkisar antara 1 hingga $6 \mathrm{~Hz}$. Akusisi data dilakukan di kawasan potensi geotermal Gunung Lamongan, Jawa Timur menggunakan alat DSS Cube 4,5 Hz yang dimiliki oleh GFZ Jerman. Pada daerah penelitian dipasang sebanyak lima alat di sekitar Gunung Lamongan. Perekaman data dilakukan selama 24 jam pada tanggal 10 Mei 2011.

\section{Potensi Geotermal Gunung Lamongan, Jawa Timur}

Jawa Timur memiliki potensi panas bumi sebesar 1206,5 MW. Potensi panas bumi sebesar 1206,5 MW berada di 11 lokasi yang tersebar di wilayah Jawa Timur. Hingga saat ini belum satupun dari 11 lokasi potensi energi panas bumi dimanfaatkan sebagai PLTP. Tiris adalah salah satu lokasi di Jawa Timur yang memiliki potensi sumber energi panas bumi untuk dikembangkan sebagai sumber energi listrik sebesar 92 MWe. Potensi energi panas bumi di Tiris di tunjukkan dengan kemunculan mata air panas yang berada di lima titik di Sungai Pekalen.

Potensi energi panas bumi ditunjukkan oleh kemunculan mata air panas di Kecamatan Tiris. Mata air panas keluar dari rekahan-rekahan pada batuan breksi andesit. Berdasarkan pada kondisi geologi dan karakteristik mata air panas yang keluar di Sungai Pekalen tersebut diinterpretasikan bahwa mata air panas di daerah ini keluar sebagai outflow aliran air panas yang berasal dari lereng Gunung Argopuro (dari timur). Daerah penelitian diinterpretasikan membentuk cekungan tapal kuda dari puncak Gunung Argopuro dan membuka kearah barat-laut (ke arah lokasi manifestasi mata air panas) pada Gambar 1. Perbedaan warna pada Gambar 1 menunjukkan perbedaan elevasi. Tiga struktur utama berupa patahan yang digambarkan dengan garis putih putus-putus merupakan struktur utama dalam sistem panas bumi Gunung Lamongan.

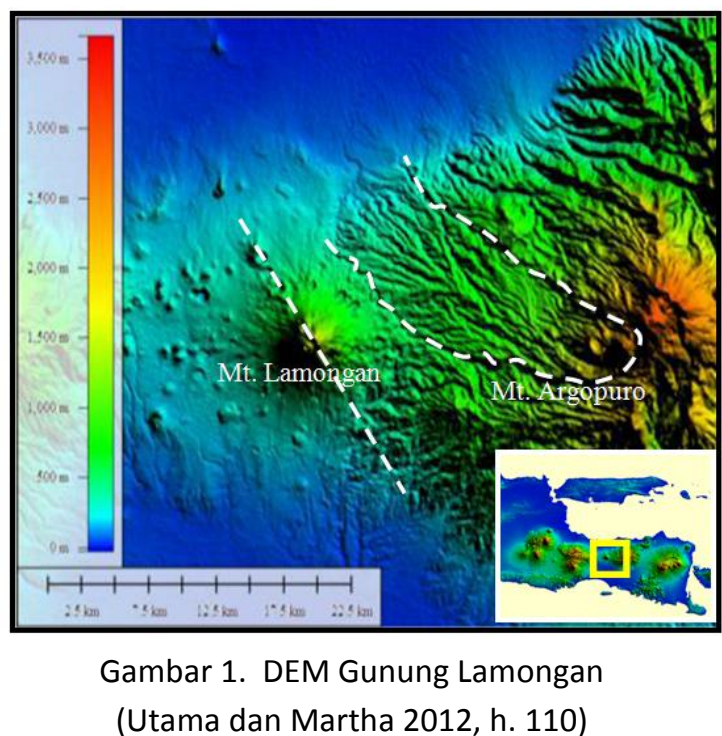


Secara morfologi, daerah penelitian merupakan lembah antara Gunung Argopuro dan Gunung Lamongan. Batuan penyusun terdiri dari lima macam yaitu: satuan batuan piroklastik Geni, lava Gunung Lamongan tua, satuan batuan piroklastik Gunung Lamongan, satuan breksi Gunung Lamongan, dan satuan breksi Gunung Argopuro dan satuan batu pasir Tarub.

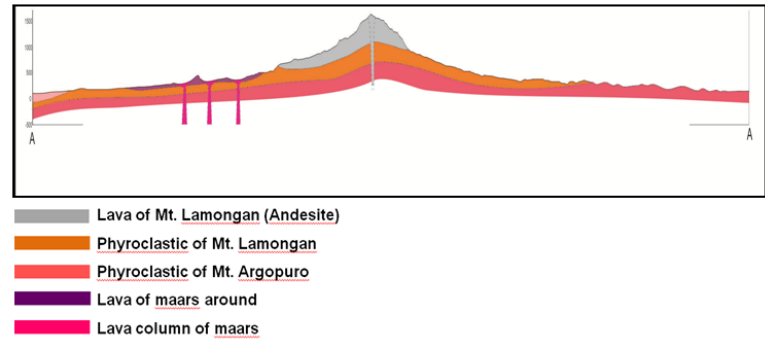

Gambar 2. Penampang Geologi Gunung Lamongan (Utama dan Martha 2012, h. 110)

Setiap warna pada Gambar 2 mewakili jenis satuan batuan berdasarkan pengamatan geologi. Warna abu-abu menggambarkan lava dari Gunung Lamongan yang merupakan batuan andesit. Warna oranye menggambarkan piroklastik Gunung Lamongan. Warna merah muda menggambarkan satuan batuan piroklastik Gunung Argopuro. Warna ungu menggambarkan satuan batuan lava pada maar di sekitar Gunung Lamongan. Warna magenta menggambarkan kolom lava dari maar sekitar Gunung Lamongan (Utama dan Martha 2012, h. 110).

\section{Ensemble Empirical Mode Decomposition (EEMD)}

Reduksi noise secara random merupakan hal terpenting dalam pengolahan data seismik, interpretasi, dan inversi. Perekaman data seismik dalam bentuk sinyal pada umumnya terdiri dari sinyal yang diharapkan dan noise yang digambarkan dengan persamaan sebagai berikut :

$$
x(t)=s(t)+n(t)
$$

$x(t)$ merupakan data berupa sinyal yang terekam, $\mathrm{s}(\mathrm{t})$ merupakan sinyal yang diharapkan, dan $\mathrm{n}(\mathrm{t})$ adalah noise. Sinyal yang terekam merupakan sinyal dalam domain waktu (t). Sehingga proses filter menghilangkan noise untuk memperoleh sinyal yang diinginkan menjadi sangat penting (Zhang et al. 2010 hh. 2104-2123).
Pada penelitian ini, metode yang digunakan untuk mereduksi noise dari perekaman data digunakan analisis EEMD (Ensemble Empirical Mode Decomposition). Proses reduksi noise pada sinyal yang bersifat non-linear dan non-stationary dilakukan dengan membagi data ke dalam panel kecil untuk diperoleh event yang linear yang disebut IMF (Intrinsic Mode Function). EEMD mendekomposisi sinyal mikroseismik menjadi sejumlah komponen berosilasi intrinsik atau disebut dengan Intrinsic Mode Function (IMF). Setiap komponen pada IMF memiliki frekuensi yang berbeda-beda. Dekomposisi ini memiliki asumsi bahwa data apapun terdiri dari berbagai model osilasi intrinsik. Setiap mode intrinsik (linear atau non-linear) merupakan osilasi yang akan memiliki jumlah ekstrim yang sama akan simetris terhadap rata-rata lokal (Wu 2004).

Huang et al. (2009) menyatakan bahwa EMD tidak bisa mengatasi permasalahan mode mixing yang disebabkan oleh gangguan pada sinyal. Untuk mengatasi hal ini, Huang et al. (2009) mensuperposisikan sinyal dengan white noise untuk menghindari mode mixing. Proses ini dikenal dengan metode Esemble Empirical Mode Decomposition (EEMD). Menurut Wu dan Huang (2009) dan Chang (2010) langkah-langkah untuk memulai analisis EEMD ialah dengan penambahan white noise domain waktu $\mathrm{w}(\mathrm{t})$ pada input data $\mathrm{x}(\mathrm{t})$ untuk mendapatkan data ditambah noise $\mathrm{X}(\mathrm{t})$. White noise $\mathrm{w}(\mathrm{t})$ ialah bilangan random berdistrbusi normal dengan rata-rata nol, varian dan standar deviasinya satu. Berikut adalah langkah-langkah metode EEMD (Ensemble Empirical Mode Decomposition) (Wu dan Huang 2009, hh. 1-41) (Wu 2004):

1. Penambahan white noise pada sinyal.

$$
X(t)=x(t)+w(t) R
$$

Dengan $\mathrm{R}$ ialah rasio standard deviasi antara amplitudo noise yang ditambahkan pada data $x(t)$.

2. Dekomposisi data dengan penambahan white noise hingga komponen ke-n pada IMF. EEMD diaplikasikan $\mathrm{X}(\mathrm{t})$ untuk mendekomposisi data $\mathrm{x}(\mathrm{t})$ sehingga menghasilkan beberapa intrinsic 
mode fuction (IMF) (c1 sampai cn) dan residu rn seperti yang tercantum pada persamaan 2 .

3. Mengulangi langkah 1 dan 2 dengan melakukan penambahan white noise wj(t) ke sinyal $\mathrm{x}(\mathrm{t})$.

4. Menentukan nilai rata-rata IMF sebagai IMF akhir.

$$
c_{i}=\frac{1}{N} \sum_{j=1}^{N} c_{i j}
$$

Selain itu, juga dilakukan menentukan rata-rata $\mathrm{rn}$ sebagai tren akhir.

$$
r_{n}=\frac{1}{N} \sum_{j=1}^{N} r_{j n}
$$

Nilai $c_{i}$ dan $r_{n}$ dinyatakan sebagai hasil akhir dengan persamaan sebagai berikut :

$$
x(t)=\sum_{i}^{n} c_{i}+r_{n}
$$

\section{METODOLOGI}

Penelitian ini dilakukan di daerah potensi geotermal Gunung Lamongan. Akusisi data dilakukan pada tanggal 10 Mei 2011 di 5 titik stasiun yang berada di sekitar Gunung Lamongan. Alat yang digunakan adalah mikroseismik portable DSS Cube EDL yang dikembangkan oleh GFZ Jerman memiliki pita frekuensi 4,5-120 Hz. Segitiga merah pada Gambar 3 merupakan posisi stasiun dan simbol bintang kuning adalah lokasi kemunculan manifestasi berupa mata air panas di Sungai Pekalen dan di Daerah Pesawahan.

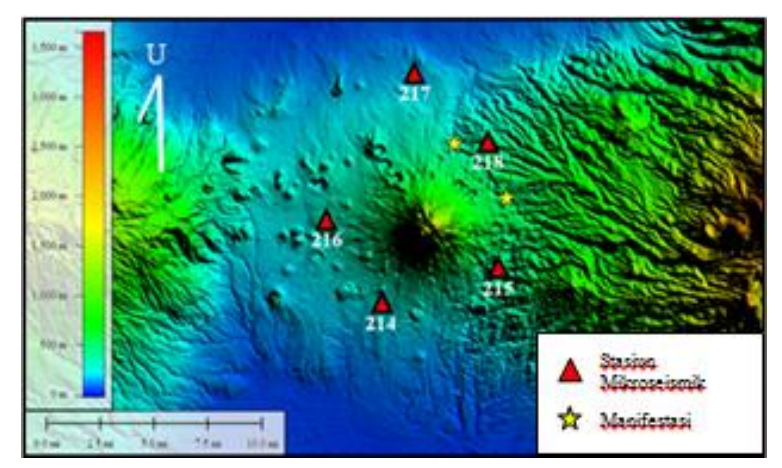

Gambar 3. Lokasi Stasiun Akusisi Data Mikroseismik

Secara garis besar penelitian ini dilaksanakan berdasarkan alur sebagai berikut :

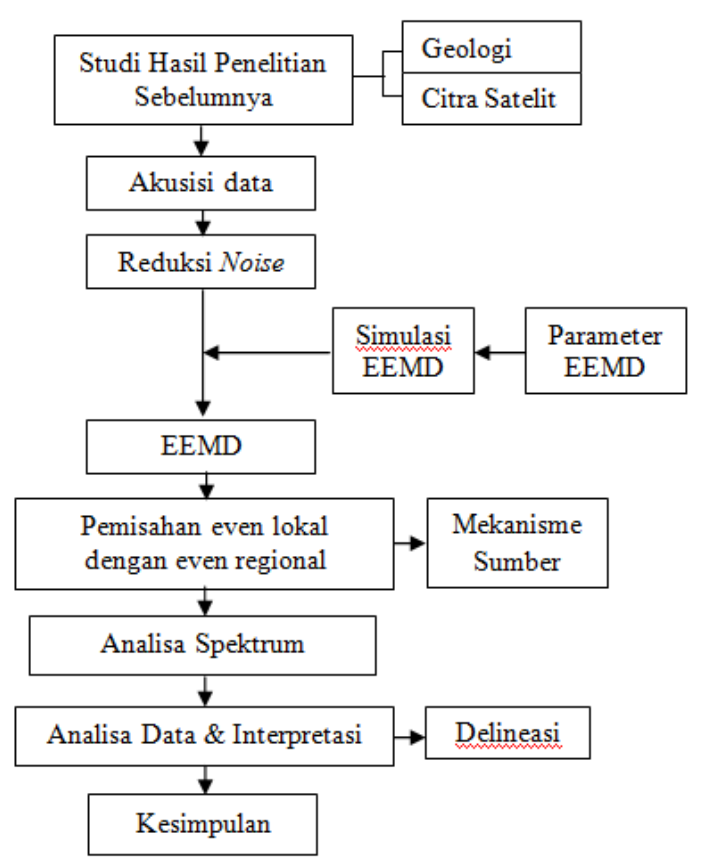

Gambar 4. Alur Penelitian Delineasi Daerah Seismik Aktif Daerah Potensi Gunung Lamongan, Jawa Timur

Data yang digunakan dalam penelitian ini adalah data komponen vertikal. Gambar 5 adalah salah satu contoh data rekaman mikroseismik komponen vertikal pada pukul $04.00-05.00$ WIB. Penentuan even lokal atau even yang berasal dari dinamika hidrotermal sangat susah karena data mengandung banyak noise. Oleh karena itu, EEMD digunakan untuk mereduksi noise pada data. Data yang telah terfilter dilakukan penentuan even lokal menggunakan metode multiplet. Metode multiplet pada penentuan even lokal dilakukan dengan membandingkan even antar stasiun dengan kejadian pada waktu yang sama.

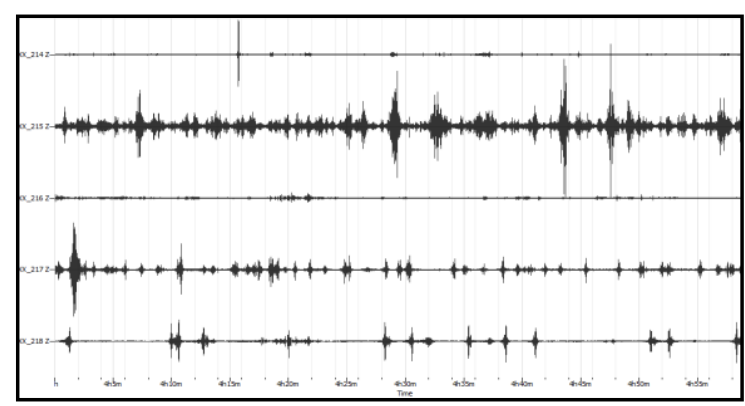

Gambar 5. Rekaman Data Mikroseismik pada Pukul

$$
\text { 04.00-05.00 WIB }
$$

Pada pengolahan data menggunakan EEMD terdapat beberapa parameter yang harus 
ditentukan sesuai dengan karakteristik sinyal data mikroseismik. Parameter yang dibutuhkan diantaranya adalah standar deviasi (R) dan jumlah pengulangan dalam proses EEMD (N). Penentuan parameter EEMD dilakukan dengan mensimulasikan dengan membuat sinyal sintetik dan noise sintetik.

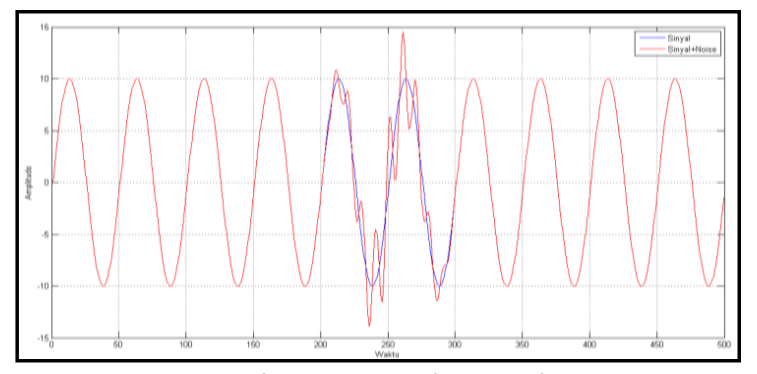

Gambar 6. Sinyal Sintetik

Sinyal sintetik diatas (Gambar 6) dibentuk dari persamaan gelombang sederhana sebagai berikut:

1. Persamaan Sinyal Sintetik.

Sinyal sintetik utama dibuat dari persamaan 6 dengan amplitude maksimum 10 .

$$
x(t)=10 \sin (2 \pi t)
$$

2. Persamaan Noise Sintetik.

Noise sintetik dibuat dari proses autokorelasi persamaan 7. Proses autokorelasi dilakukan untuk diperoleh sinyal dari even suatu getaran.

$$
n(t)=0.5 \sin (2 \pi t)
$$

Sinyal sintetik pada Gambar 6 diperoleh dari hasil penjumlahan sinyal utama sintetik dengan noise sintetik. Garis merah menyatakan sinyal yang mengandung noise. Garis biru menggambarkan sinyal utama sintetik. Hasil simulasi dihasilkan nilai standar deviasi $(R)=0,1$ dan nilai $N=75$. C1 pada Gambar 7 adalah komponen pertama yang merupakan input data. Komponen 2 hingga 8 merupakan proses penguraian sinyal utama menjadi beberapa komponen IMF. Hasil optimal yang menggambarkan sinyal kembali kepada bentuk semula atau amplitudo sinyal tepat pada 10 terjadi pada komponen ke-4 atau C4. C9 adalah sisa atau residu dari operasi EEMD.

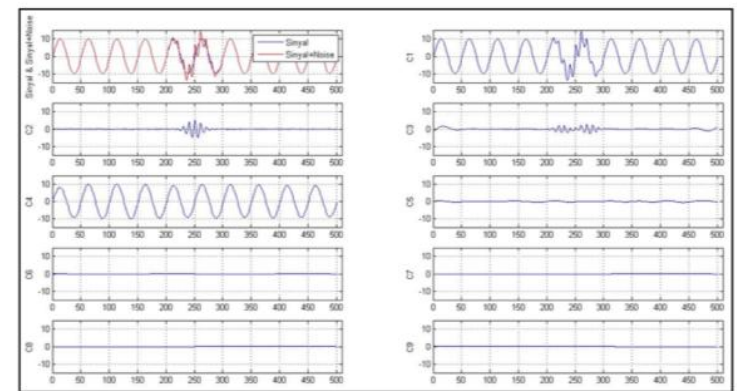

Gambar 7. Hasil Simulasi EEMD Menggunakan Parameter Standar Deviasi 0,1 dan Perulangan (N) 75

\section{HASIL DAN PEMBAHASAN}

Proses monitoring atau identifikasi tingkat seismisitas skala mikro daerah potensi geotermal dapat dilakukan menggunakan pengukuran mikroseismik. Sinyal rekaman mikroseismik tidak lepas dari keberadaan noise yang berasal dari sekitar stasiun mikroseismik. Reduksi noise adalah hal pertama yang dilakukan untuk melakukan analisis selanjutnya. Noise dapat menyembunyikan informasi dinamika hidrotermal bawah permukaan. Hal ini disebabkan karena noise memiliki frekuensi yang lebih tinggi dibandingkan dengan even lokal. Dalam hal ini, even lokal dinyatakan sebagai even yang berasal dari dinamika hidrotermal. Pada penelitian ini menggunakan metode EEMD untuk mereduksi noise.

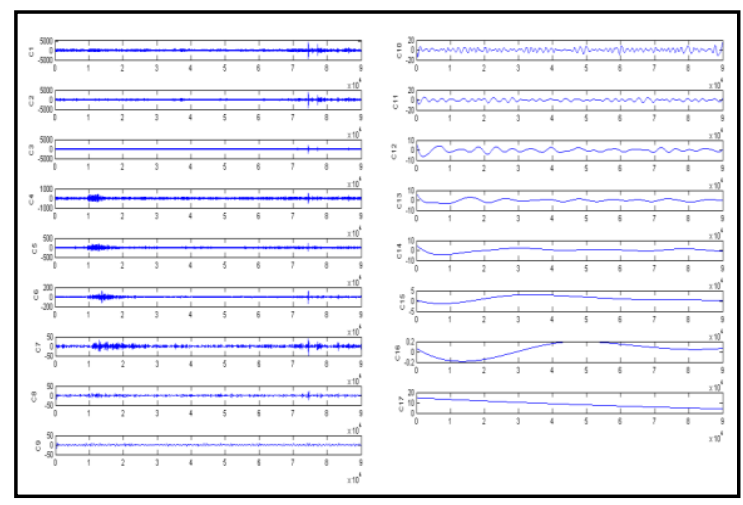

Gambar 8. Hasil Proses Operasi EEMD pada Sinyal Mikroseismik Stasiun 214 Pukul 04.00-05.00 WIB 
Gambar 8 menunjukkan penguraian sinyal rekaman seismik menjadi beberapa komponen IMF dalam proses EEMD. Informasi even dan sinyal terbebas noise terjadi pada komponen ke-5 atau C5. Sehingga C5 pada setiap operasi EEMD masingmasing stasiun digunakan untuk menentukan even lokal menggunakan metode multiplet. Secara kualitatif, even lokal memiliki ciri yaitu amplitudo atau envelope perubahannya tidak signifikan atau sinyal tipe successive (Errington et al 2005, hh. 246250).

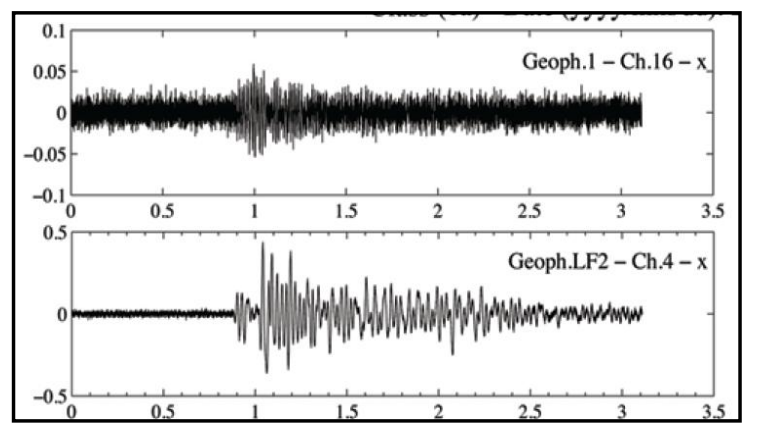

Gambar 9. Tipe Sinyal Rekaman Mikroseismik Successive Memiliki Frekuensi Rendah $<50 \mathrm{~Hz}$ (C.Occhiena, 2012)

Sinyal mikroseismik bercirikan banyaknya noise yang dapat terlihat pada Gambar 9 diatas yang terletak di bagian kanan dan kiri dari sinyal even.

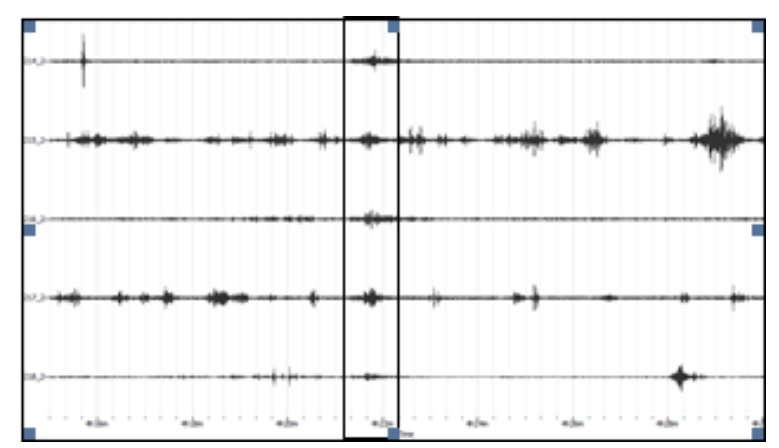

Gambar 10. Penentuan Even Lokal Berdasarkan Kesamaan Waktu Tiba Gelombang P atau dengan Menggunakan Metode Multiplet

Kolom pada Gambar 10 memberikan gambaran kejadian dari even lokal yang diinterpretasikan berasal dari dinamika hidrotermal bawah permukaan. Beberapa even masih tampak selain even lokal. Even tersebut tidak dapat direduksi sepenuhnya dikarenakan perbedaan frekuensi antara even lokal dengan noise terlalu besar. Oleh karena itu, hal ini merupakan salah satu kelemahan dari operasi EEMD. Untuk memastikan karakter even lokal dilakukan analisis secara kuantitatif menggunakan analisis spectrum amplitude. Spectrum amplitude dilakukan untuk mengetahui rentang frekuensi dari even lokal. Perubahan domain waktu menjadi domain frekuensi dilakukan dalam analisis spectrum amplitude untuk mengetahui sebaran frekuensi pada sinyal.

Gambar 11 adalah salah satu hasil analisis spectrum amplitude sinyal rekaman data pada pukul $04.00-05.00$ WIB. Sumbu x menyatakan waktu dan sumbu y menyatakan frekuensi. Perbedaan warna pada Gambar 11 menyatakan nilai energi sinyal. Secara berurutan dari atas adalah spectrum amplitude pada stasiun 214 hingga 218. Kotak hitam menyatakan spectrum amplitude pada lokal even. Spectrum amplitude menunjukkan bahwa rekaman dinamika hidrotermal berada pada rentang frekuensi 1 hingga $5 \mathrm{~Hz}$. Setiap even lokal yang terekam oleh masing-masing stasiun akan dilakukan akumulasi statistik untuk mendelineasi daerah seismik aktif Gunung Lamongan berdasarkan intensitas rekaman kejadian even lokal.

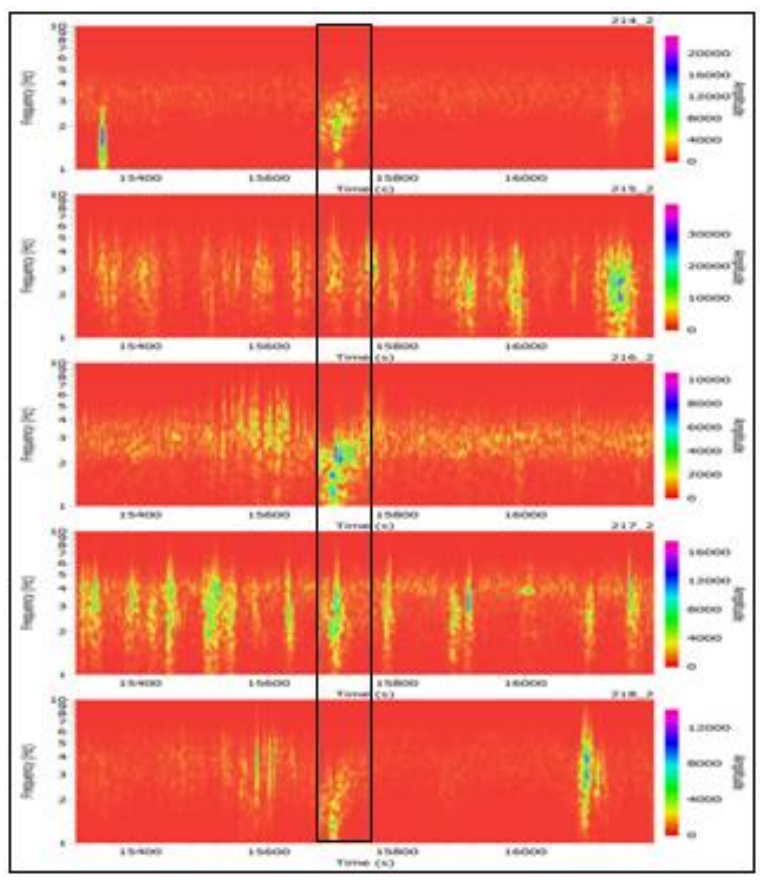

Gambar 11. Hasil Analisa Spectrum Amplitude Rekaman Data pada Pukul 04.00-05.00 WIB 
Tercatat terdapat 8 even lokal dan 1 even regional. Even regional merupakan even gempa skala besar atau lebih besar dari 3 SR. Gempa tersebut merupakan gempa tektonik yang terjadi di utara Molucca. Gempa regional tersebut terekam pada pukul 14:48:27,83 WIB. Info gempa yang diperoleh dari website www.webdc.eu bahwa gempa tersebut berada pada kedalaman $50 \mathrm{Km}$ dengan kekuatan gempa 5,1 SR. Even regional ini memiliki frekuensi 9,51 hingga 12,93 atau yang tercantum pada tabel 1 di even mikroseismik ke-8.

Tabel 1. Rekapitulasi Even Lokal Berdasarkan Waktu Tiba Gelombang P dan Frekuensi pada Masing-masing Stasiun

\begin{tabular}{|c|c|c|c|c|c|c|}
\hline No & \multicolumn{5}{|c|}{ Frekuensi (Hz) } & \multirow{2}{*}{ Keterangan } \\
\hline Stasiun & 214 & 215 & 216 & 217 & 218 & \\
\hline 1 & 2,82 & 3,03 & 3,30 & 4,85 & 1,54 & Even Lokal \\
\hline 2 & 1,66 & 2,44 & 2,38 & 2,35 & 1,51 & Even Lokal \\
\hline 3 & - & - & 2,53 & 2,38 & 3,18 & Even Lokal \\
\hline 4 & - & 2,11 & 2,59 & 2,27 & 2,06 & Even Lokal \\
\hline 5 & 4,20 & 4,35 & - & 4,05 & - & Even Lokal \\
\hline 6 & - & - & 2,44 & 3,68 & 2,79 & Even Lokal \\
\hline 7 & 2,11 & - & 2,75 & 2,22 & 3,07 & Even Lokal \\
\hline 8 & 10,32 & - & 12,93 & 11,91 & 9,51 & Even Regional \\
\hline 9 & 2,16 & 2,19 & 2,89 & 1,89 & 2,04 & Even Lokal \\
\hline
\end{tabular}

Delineasi ini merupakan asumsi atau perkiraan awal berdasarkan intensitas rekaman even pada setiap stasiun. Delineasi zona seismik aktif daerah potensi Gunung Lamongan terbagi menjadi 2 kategori. Kotak kuning adalah daerah seismik aktif dari dinamika hidrotermal bawah permukaan yang dapat ditunjukkan dengan adanya struktur kerucut dan beberapa maar di bagian barat Gunung Lamongan. Kenampakan struktur geologi ini dapat diinterpretasikan adanya dinamika hidrotermal yang mengintrusi sehingga membentuk pola kerucut di permukaan.

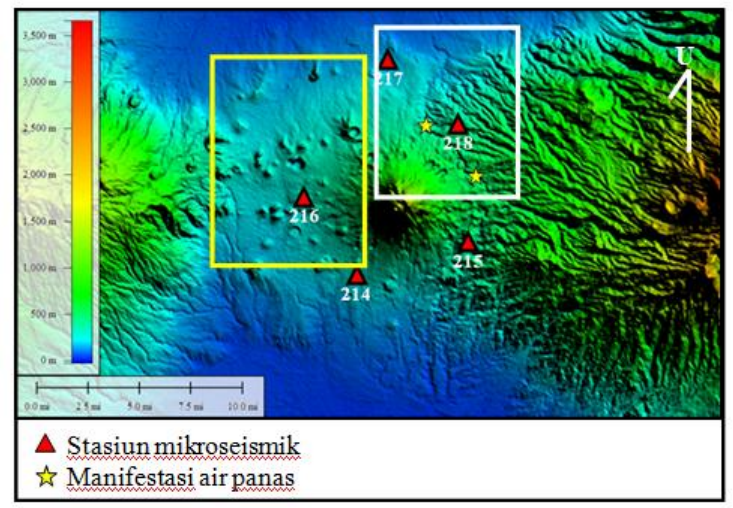

Gambar. 12. Delineasi Zona Seismik Aktif Kawasan Potensi Geotermal Gunung Lamongan.

Kotak putih merupakan daerah seismik aktif dari pergerakan hidrotermal yang ditunjukkan adanya manifestasi. Pergerakan fluida yang naik ke permukaan melalui media permeable berupa patahan mengakibatkan terjadinya sumber getaran skala kecil atau mikro yang direkam oleh stasiun 217 dan 218. Oleh karena itu, stasiun 217 dan 218 merekam pergerakan hidrotermal lebih inten dibandingkan stasiun lainnya. Kedua daerah delineasi ini merupakan daerah seismik aktif yang berada di bagian utara dan barat Gunung Lamongan. Untuk mengetahui posisi episenter dan hiposenter dapat dilakukan analisa lebih lanjut. Hasil penelitian ini merupakan studi pendahuluan sebelum dilakukan pengukuran metode mikroseismik dengan pita frekuensi yang lebih lebar atau memiliki rentang frekuensi 0,01 hingga 1000 Hz. Studi pendahuluan ini digunakan untuk membantu desain akusisi stasiun dan menjadi referensi untuk metode pengukuran geofisika lainnya. 


\section{PENUTUP}

\section{Simpulan}

Hasil analisis proses reduksi noise menggunakan metode EEMD untuk identifikasi dinamika hidrotermal bawah permukaan dapat disimpulkan sebagai berikut:

1. Even seismik lokal adalah sumber sekunder dalam rekaman data mikroseismik sedangkan sumber primer sinyal rekaman mikroseismik berupa sinyal utama dan noise.

2. Parameter standar deviasi dan batas perulangan pada metode EEMD yang digunakan untuk reduksi noise pada data mikroseismik adalah 0,1 dan 75.

3. Even lokal memiliki frekuensi rendah antara 1 hingga $5 \mathrm{~Hz}$ untuk studi kasus daerah potensi geotermal Gunung Lamongan.

4. Even regional atau gempa tektonik yang terekam oleh alat memiliki frekuensi antara 9,51 hingga $12,93 \mathrm{~Hz}$.

5. Tercatat 8 even lokal dan 1 even regional dari gempa tektonik yang terjadi pada pukul 14:48:27.83 WIB di utara Laut Molucca pada tanggal 10 Mei 2011.

6. Daerah seismik aktif berada di bagian utara Gunung Lamongan yang bersumber dari intrusi hidrotermal membentuk struktur kerucut dan pergerakan hidrotermal ke permukaan ditunjukkan dengan manifestasi air panas.

\section{Ucapan Terima Kasih}

Penulis mengucapkan terima kasih kepada GFZ Germany dan Dinas ESDM Provinsi Jawa Timur kerjasama penelitian dengan ITS khususnya dalam kegiatan eksplorasi panas bumi di Jawa Timur. Hasil penelitian ini merupakan bagian dari program kerjasama riset antara ITS dengan GFZ dan Dinas ESDM Jawa Timur. Penulis juga perkenankan menyampaikan ucapan terima kasih kepada Jurusan Teknik Geofisika ITS yang telah memberikan bantuan fasilitas pengolahan data selama penelitian.

\section{DAFTAR PUSTAKA}

Angus Errington, B.L.F Daku, David Dodds, Amfinn Prugger, 2005. Characterization of the energy spectral density for a potash mine. Proceedings of the IEEE Canadian Conference on Electrical \& Computer Engineering, hh. 246-250.

C. Occhiena, V. Coviello, M. Arattano, et al., 2012. Analysis of microseismic signals and temperature recording for rock slope stability investigations in high mountain area, Natural Hazard Earth System. Sci., 12, hh. 2283-2298.

Erik H. Saenger, Stefan M. Schmalholz, Marc-A. Lambert, dkk., 2009. A passive seismik survey over a gas field: Analysis of Low-Frequency Anomalies, Geophysic, 74(2), hh. 29-40.

Jiang Zhang, Ruqiang Yan, Robert X Gao, Zhihua Feng., 2010. Performance enhancement of ensemble empirical mode decomposition. Mechanical System and Signal Processing, 24, hh. 2104-2123.

Po-Hong Wu., 2004. Time-Frequency Analysis and Wave Transform Term Paper Tutorial Hilbert Huang Transform for Climate Analysis. Graduate Institute of Communication Engineering, National Taiwan University.

Sylvette Bonnefoy-Claudet, Fabrice Cotton, Pierre-Yves Bard., 2006. The Nature of Noise Wavefield and Its Application for Site Effects Studies A Literature Review, Earth-Science Review, 79. ELSEVIER. hh. 205227.

Wei Chen, Shangxu Wang, Zhen Zhang, Xiaoyu Chuai., 2012. Noise Reduction Based on Wavelet Threshold Filtering and Ensemble Empirical Mode Decomposition, SEG Annual Meeting, Las Vegas, hh.1-5.

Widya Utama, Tri Martha KP., 2012. Fracture Modeling Using Azimuthal Resistivity Sounding Method in Geotermal Manifestations of Gunung Lamongan, East Java. Proceedings 1st ITB Geothrermal Workshop, h. 110.

Zhaohua Wu, Norden E. Huang, 2009. Esemble Empirical Mode Decomposition: A Noise-Assited Data Analysis Method, Advances in Adaptive Data Analysis 1(1), hh. 1-41. 